\title{
Business for sustainable change : Extending eco-efficiency and eco-sufficiency strategies to consumers
}

\section{Heikkurinen, Pasi Petteri}

2019-05-01

Heikkurinen , P P , Young , C W \& Morgan , E 2019 , ' Business for sustainable change :

Extending eco-efficiency and eco-sufficiency strategies to consumers ', Journal of Cleaner

Production , vol. 218 , pp. 656-664 . https://doi.org/10.1016/j.jclepro.2019.02.053

http://hdl.handle.net/10138/326053

https://doi.org/10.1016/j.jclepro.2019.02.053

acceptedVersion

Downloaded from Helda, University of Helsinki institutional repository.

This is an electronic reprint of the original article.

This reprint may differ from the original in pagination and typographic detail.

Please cite the original version. 
ACCEPTED FOR PUBLICATION, PRE-PRINTED VERSION

(C) The Authors

Reference: Heikkurinen, P., Young, C. W., Morgan, E. (2019). Business for sustainable change: Extending eco-efficiency and eco-sufficiency to consumers, Journal of Cleaner Production, 1-28, in print.

\title{
Business for sustainable change: Extending eco-efficiency and eco-sufficiency strategies to consumers
}

\author{
Pasi Heikkurinen $^{\mathrm{a}, \mathrm{b}}$, C. William Young ${ }^{\mathrm{a}}$, Elizabeth Morgan ${ }^{\mathrm{a}}$ \\ ${ }^{a}$ Sustainability Research Institute, University of Leeds, UK \\ ${ }^{\mathrm{b}}$ Department of Economics and Management, University of Helsinki, Finland
}

\begin{abstract}
A variety of stakeholders are calling for businesses to take action regarding the prevailing unsustainable development. This article examines how firms operating on the micro-level could effectively address issues of sustainability on the macro-level. It is proposed that companies adopting extended eco-efficiency and eco-sufficiency strategies can effectively contribute to sustainability. This 'extension' in business strategy for sustainable change signifies that firms both increase the quality of production (eco-efficiency) and decrease the amount of production (eco-sufficiency) in their operations, as well as influence customers to consume both better (extended eco-efficiency) and less (extended eco-sufficiency). The article argues that due to their power and position in the supply chain, multinational companies of significant brand value are well suited to change production and consumption patterns through extended eco-efficiency. The extended eco-sufficiency strategy is considered to require support from non-commercial actors.
\end{abstract}

Keywords: Business; consumers; change; eco-efficiency; eco-sufficiency; sustainability 


\section{Introduction}

It is now commonly accepted that the prevailing unsustainability is closely coupled with economic activities. On the aggregate level, the quality of economic activities is considered to be poor and too inefficient, while the quantity of economic activities is claimed to be too extensive - both leading to large-scale problems in the biosphere (Daly, 1992; IPCC, 2014). As these macro-level problems are outcomes of microlevel decisions and operations, there is a need to study the potential, as well as the limitations, of commercial actors to spur sustainable change.

Responsible companies and consumers have already reacted to the challenge of sustainability by exploring alternatives to the business as usual. Previous studies have noted that consumption and production, as well as the distribution of goods and services, are undergoing an ethical turn. On the demand side, studies have reported a so-called greening of consumer attitudes and behaviour (Fisher et al., 2012; EC, 2014) and a rise in ethical consumerism (Memery et al., 2005; Newholm and Shaw, 2007), and also the emergence of green consumers (Moisander and Pesonen, 2002; Autio et al., 2009). On the supply side again, private enterprises are reported to take increased responsibilities for a variety of sustainability issues (Heikkurinen and Mäkinen, 2018), which has manifested in the development of green products and services (Albino et al., 2009; Dangelico and Pujari, 2010), as well as new business models (Bocken et al., 2014; Stål and Corvellec, 2018).

Sustainable change in business and consumption, however, is often theorised through the notion of eco-efficiency, which prescribes a win-win strategy to arrive at a less damaging use of natural resources along with financial savings for the company (DeSimone and Popoff, 2000; Hukkinen, 2001). These eco-efficiency strategies are in line with weak sustainability theorising, as they assume substitutability between different forms of capitals, as well as focus on relative efficiency gains, largely ignoring the rebound effect (Heikkurinen and Bonnedahl, 2013; Fuchs et al., 2016). By contrast, strong sustainability calls for eco-sufficiency as a strategy to ignite sustainable change (Bonnedahl and Heikkurinen, 2019). In strongly sustainable business, complementarity of capitals is assumed, limits to growth are acknowledged (Dyllick and Hockerts, 2002; Heikkurinen and Bonnedahl, 2013; Stål, 2018), and overall consumption levels and patterns are addressed (Lorek 
and Fuchs, 2013). A question that has been largely overlooked is the role of companies to ignite both sustainable change (in terms of both weak and strong sustainability) beyond their own operations (see e.g. Stål and Jansson, 2017).

This article examines how businesses operating on the micro-level could effectively contribute to sustainability on the macro-level. The focus of the study is on the potential and limitations of multinational brand companies acting as change agents in relation to sustainable production and consumption. Based on the review, the study notes that business strategies in line with weak sustainability focus on the quality aspect of sustainable production and consumption by means of ecoefficiency, while strongly sustainable strategies emphasis the quantity by means of eco-sufficiency. The article claims that both eco-efficiency and eco-sufficiency should be integrated in business strategies to ignite sustainable change. Moreover, firms can amplify their contribution to sustainability by influencing their customers to consume better and less. This shift from unsustainability to sustainability in business is undoubtedly difficult as companies operate with competing logics, agents and mechanisms of change in different spheres of action.

The article begins by reviewing previous work on change (section 2). In section 3 , the article analyses under what conditions businesses could act as agents of effective sustainable change, followed by a discussion on the micro-micro tensions, as well as means to overcome them (section 4). In section 5, conclusions are presented.

\section{Reviewing catalysts of change}

The catalysts of change are certainly diverse and operate in distinct spheres of activity. Drawing on the systems theory framework, which is often used in sustainability studies to study the interplay of macro and micro levels of analysis (Starik and Rands, 1995; Van Marrewijk and Werre, 2003), this article locates the catalysts of change in three distinct spheres. Those spheres are the private sphere, which encompasses economic systems; the public sphere, which includes legal and political systems; and the biosphere, which is the sum of all ecosystems. While the spheres overlap, each has a distinct operational logic for change, different 
assumptions in terms of who are the change agents, and consequently encompasses varying mechanisms for change (Table 1).

Table 1. Catalysts of change

\begin{tabular}{|c|c|c|c|}
\hline & Private sphere & Public sphere & Biosphere \\
\hline Change logic & $\begin{array}{l}\text { Market logic in which the 'invisible hand' guides } \\
\text { change }\end{array}$ & $\begin{array}{l}\text { Democratic logic in which the 'visible hand' } \\
\text { guides change }\end{array}$ & $\begin{array}{l}\text { Eco-logic in which the 'nonhuman hand' guides } \\
\text { change }\end{array}$ \\
\hline Change agents & Consumers, producers, businesses & Citizens and governments & The Earth, non-humans \\
\hline $\begin{array}{l}\text { Change mechanisms } \\
\text { (examples) }\end{array}$ & $\begin{array}{l}\text { Price, choice editing, collaborative consumption, } \\
\text { lifestyle management }\end{array}$ & $\begin{array}{l}\text { Laws, regulations, policies, taxes, } \\
\text { incentives, subsidies }\end{array}$ & $\begin{array}{l}\text { Ecological catastrophes (e.g. volcano eruptions, } \\
\text { droughts, floods) }\end{array}$ \\
\hline
\end{tabular}

In the private sphere, activities operate mainly by the market logic in which change is brought about by an invisible hand. This means that to ignite change, agents are encouraged to partake in the exchange of goods and services in the market place for their own interest. The laws of supply and demand would then determine the prices for goods and services and distribute wealth in a just and efficient manner. In the Wealth of Nations, Adam Smith ([1776] 2012) coined this idea of the invisible hand, which was to produce desired change for the benefit of all when markets were allowed to operate freely without government intervention. Hence, he suggested that the most effective way for actors to benefit society is to pursue their self-interest in the market place - and this is largely where the private sphere continues to derive its logic.

The central change agents in the private sphere are assumed to be the individual consumers, but also producers and distributors who can affect supply. The role of consumers is to act in the market place according to their needs and wants, while businesses ought to take care of the supply. However, it is important to note that companies have not only a responsive (both reactive and proactive) role in relation to the demands of customers (see e.g. Murillo-Luna et al., 2011) but are also important agents in creating and boosting new demand for sustainable products (Heikkurinen and Forsman-Hugg, 2011). In addition to the most effective way of influencing supply and demand, which arguably is price, businesses use a variety of means to 'nudge' consumer behaviour through marketing and retail design in order to present choices to individuals in ways in which the desired option is encouraged (Thaler and Sunstein, 2008).

In the public sphere the logic behind change is a democratic one. The idea of democracy, which first appeared in ancient Greece and was famously developed by 
Plato in The Republic, advocates that the majority of its citizens should rule a society instead of an elite. If the metaphor for the rule of the market and individual choice is the invisible hand, democratic rule could be considered to manifest in the visible hand of the commoner. In other words, in the practices within the public sphere, it is the visible hand that is assumed to create any change. The main change agents in the public sphere are considered to be the citizens and the government, as most of the contemporary democracies are representative to some degree. Consequently: laws, regulations, policies, taxes, incentives, and subsidies are used as the main mechanisms to generate sustainable change in a society.

This article now sets out a third sphere in which change takes place; it is the sum of all ecosystems, the biosphere. The kind of change logic that underpins the operation of the biosphere remains rather opaque to humans, but some of its laws have been revealed. To acknowledge this logic of the biosphere as a source of change, the current article refers to it as eco-logic. In this sphere, it is the non-human hand that is behind change, and its scale spans from micro-organisms to the planetary scale. It builds from Norgaard's (1994) coevolutionary framework, which included the coevolution of environment, knowledge, organisation, technologies, and values. This was also the foundation of Foxon's (2011) later coevolutionary framework, which specified ecosystems as one of the coevolving systems. Examples of how the natural world can change human behaviour are myriad ranging from influenza and other diseases to earthquakes, droughts, floods, and volcanic eruptions that influence behaviour in the private and public spheres. Moreover, as climate change proceeds apace, more extreme weather events can be expected, as noted by the IPCC (2014) among others. As Barad (2003) has it, nature itself, not merely human representations of it, has agency. Hence the role of non-humans as change agents should not be excluded from any thorough analysis of economic (or human) activity (see Heikkurinen et al., 2016). The Earth and its beings are the central agents of change and consequently, any ecological changes, be they catastrophes or others, can be considered to serve as mechanisms of change.

Figure 1 demonstrates, how economic agents - be they mainstream consumers, mainstream business, ethical consumers or ethical business actors - operate within the private sphere, which is embedded in the broader historical and cultural fabric of society, which in this study is referred to as the public sphere. The private sphere 
comprising an economic system operates with a market logic based on the principle of 'one dollar, one vote.' As noted earlier, this principle is notably different from the logic of legal and political systems, where each person is viewed as one vote. It is this difference between the logics and principles of the private and public spheres that continues to create tensions between contemporary society and the marketplace (Heikkurinen and Mäkinen, 2018) where boundaries between the spheres are blurred (Scherer and Palazzo, 2011). For business strategies, this means that managers and employees, and also consumers, must operate within multiple spheres of practice with conflicting logics. Business managers undertaking routine activity must address the question of which logic to follow. Business has certainly been influenced by the conventional market logic, but through the amalgamation of supply and demand, such as collaborative consumption and stakeholder thinking, the democratic element of decision-making is increasing its importance.

Figure 1. The interplay of influence between actors in different spheres (arrows represent influence)

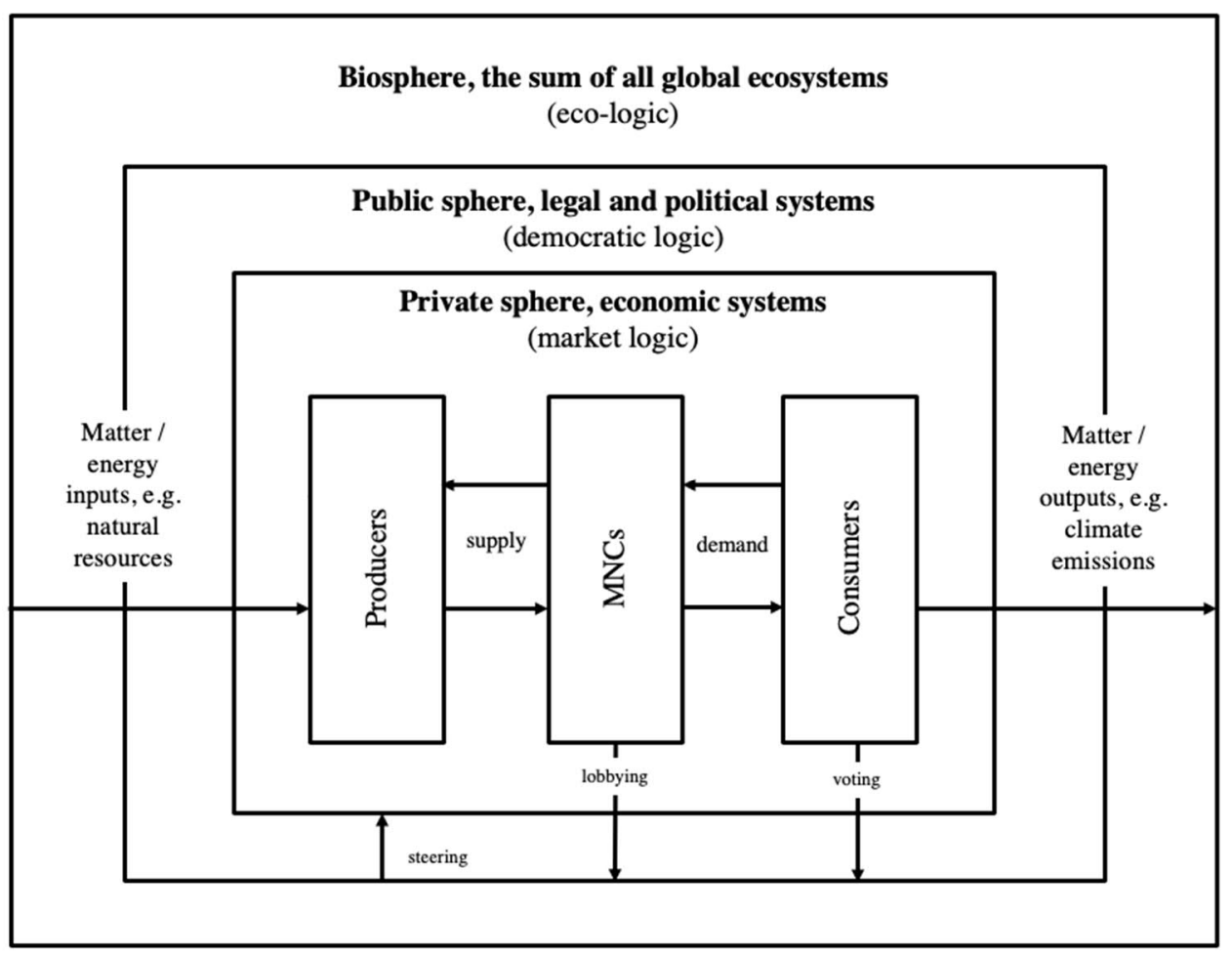

As Figure 1 shows, the private and public spheres, in turn, operate within the biosphere, the sum of all global ecosystems, and its eco-logic.. In the Anthropocene, 
where humans have become a global force interfering with most ecological processes and systems, the role of humans is obviously too significant. While the boundaries between the human or human-made spheres (the public and private) and the natural environment (the biosphere) are blurring, non-human objects still have a degree of independence from humans, as well as a natural mechanism to adhere to. This coevolutionary argument means that businesses are not only influencing the ecosystem but also being influenced by it. The flow of matter/energy inputs that enter the public and private spheres (e.g. fossil fuels) are the clearest example of this influence, which signifies human enterprises dependence on the natural environment. Their matter/energy outputs are the major way in which businesses and consumers affect the biosphere. All of the matter and energy consumed turns into waste and emissions that exit the private sphere as externalities, but do not exit the biosphere. The costs of the externalities carry into the public sphere, which further highlights the interplay between the different spheres. All this means that consumers and business actors aiming to become sustainable in their operations would also have to understand these basic eco-logics and take them into account in everyday activities.

Figure 1 also depicts how the mechanisms through which businesses can spur change for sustainability are not limited to the business-consumer interface. Powerful multinational companies (MNCs) in particular increasingly engage in the public sphere through lobbying activity that influences legal and political processes, as well as by creating multi-stakeholder initiatives that unite groups and individuals on a social or environmental issue. An example of this kind of quasi-political organising is the Global Reporting Initiative, where companies work together with consumers and other stakeholders to set standards for themselves and legitimise their actions in the eyes of the public. This article focuses on multinational consumer brand companies because they have the potential to ignite major changes due to their enormous power and influence on governments and their millions of mainstream customers.

The role of mainstream and ethical businesses is also different. It must be accepted that not all consumers and businesses are as fully engaged in sustainability and open to the required change. While the mainstream actors adopt and reproduce the values and activities of the masses, the ethical agents pursue different strategies. Moreover, 
when an ethical consumer or business engages in an alternative activity it is likely to also influence the mainstream actors. So, it is not only other actor groups that can generate the desired change but influence takes place also within actor groups: consumers influence other consumers, for instance.

\section{Analysing businesses as change agents}

While sustainable business and consumption are often considered to reside in market transactions (Dyllick and Hockerts, 2002; Heikkurinen and Bonnedahl, 2013), there are also approaches to sustainability that have emphasised central and local government initiatives. These can include providing the infrastructure (e.g., household recycling bins), legal structures (e.g., vehicle emission related taxes), incentives (e.g., such as renewable energy technology subsidies) and related information campaigns to change the attitudes and behaviour of people (Auld et al., 2014). While these attempts have had their successes, they are unlikely to yield all that will be required, in the current neoliberal political environment, where the role of the government and the regulatory intervention in the market are being minimised (see Castree, 2010). Moreover, the democratic logic of the public sphere is often considered to be too slow and inefficient in responding to the signals of the market, and hence the private sphere operating with a market logic is increasingly the predominant way of organising the commercial activities of a society. Consequently, what many highly industrialised societies have today are companies and consumers driving change in varying ways.

While the marketing of products to customers with declared green values is nothing new (Shrum et al., 1995), it has recently become apparent that businesses are augmenting their influence over consumers beyond their traditional responsibilities as producers or distributors of goods and services. The article sees this new business goal of changing the ways in which consumers use products and services that are sold to them, as potentially being motivated by at least three different reasons.

The first is that progressive companies have found that, for consumer goods and services, the results of ecological lifecycle assessments showed that the use phase can bring the highest environmental load (Girod et al., 2014). This is often because 
climate emissions in use and product disposal at the end of use are more significant in the consumption phase of a lifecycle. Secondly, competitive aims are driving companies to take their environmental and social responsibilities (beyond compliance) into account (Porter and Kramer, 2006; Heikkurinen and ForsmanHugg, 2011). Heikkurinen (2010), for instance, notes that responsible companies can enhance their strategic position through internal and external differentiators from competitors - as the firm becomes a more preferred employer, partner, and supplier - and benefit from enhanced employee motivation, cost savings, better reputation, and greater customer loyalty. Schaltegger et al.'s (2012) review again finds six categories of business case drivers for sustainability, adding the additional financial factors of sales and profit, risk reduction and innovative capability to the above.

While firms' attempts to decrease their wider footprints have been largely overlooked in sustainable consumption and production literature (cf. Bocken and Allwood, 2012), government seem to consider companies (and particularly retailers) to be important agents of change. Albeit perhaps insufficient, recent research has shown that UK retailers, for instance, have made substantial progress in terms of eco-efficiency driven by financial businesses cases (Sullivan and Gouldson, 2017). In addition, some companies have been seeking to reduce the environmental impact arising from consumption of the products they sell.

Moreover, governments have seen that big brand companies often have a closer relationship with, and hence potential influence over, consumers than governments do over their citizens (Goworek et al., 2013). Therefore, companies are increasingly pushed by the government and quasi-autonomous non-governmental organisations (quangos) to be involved in cross-industry partnerships and voluntary agreements, as well as to play a leading role in reducing the environmental impact of the use phase of their products and services (Spaargaren and Mol, 2008; Bocken and Allwood, 2012). Representing the interests of their consumers (gained from regular customer research) to governmental bodies can be seen as the natural extension of companies' relationships with the consumer-citizen (Barr et al., 2011a). Some large international businesses, for example, use the World Economic Forum in Davos to push their own and their customers' sustainability agenda into government policy (WEF, 2013). 
The pressure and engagement from government, as well from other stakeholders, is predominantly aimed at multinational consumer-brand corporations who are the manufacturers or large retailers of (often fast moving) consumer goods. As a consequence, these business organisations have invested significantly in policies, systems, and resources to manage sustainability issues in their operations and supply chains; and as mentioned above, this organisational change towards sustainability has mostly been in the sphere of eco-efficiency, where there is an easily conceivable win-win situation relating to both the sustainability issue and the financial bottom line of the company (DeSimone and Popoff, 2000; Dauvergne and Lister, 2012).

The reasons for corporate engagement in changing consumption are often mixed and myriad, as are the means for doing so. The ways brand companies influence their consumers, however, can be divided into two main categories, namely direct and extended mechanisms. Morgan (2015) highlights two direct ways in which retailers are interacting with their consumers. In choice editing, retailers decide to offer only a greener product range or those with a sustainability label (such as that from the Rainforest Alliance), forcing the consumer into buying those greener products within particular product categories (Boyes et al., 2009). Hence, businesses 'proactively construct the shape and constraints for consumers' consumption choices' (Morgan, 2015, p. 76). As coffee and tea categories are commonly choice edited in UK supermarkets (Lang and Barling, 2012), it is made convenient for consumers to buy ethically.

In addition to choice editing within product categories, retailers are also able to select in advance what categories of goods will be acceptable, rather than allowing them to emerge from consumer preferences (Morgan, 2015). For instance, Solomon and Rabolt (2004) state that retailers decided that fur would no longer be fashionable, while Peattie and Belz (2010) point out that some UK retailers have decided to delist patio heaters entirely, owing to the heaters directly contributing to climate change. Lee et al. (2012) again assert that retailers stocking, displaying, and featuring whole ranges of environmentally less-harmful products result in the whole category becoming more accessible to consumers. These two example mechanisms could be seen as businesses directly influencing more ethical consumption from the sustainability point of view. 
In addition to direct influences, companies can exert extended influence on consumers. An extended influence refers to the situation when businesses adopt more engaged ways to tackle the use phase by encouraging the consumer-citizen to become more efficient and reduce energy and waste when using the product or service. Some noteworthy examples include Unilever, Procter and Gamble, and Marks and Spencer aiming to change the laundry habits of their consumers to reduce the temperature clothes are washed at (Business in the Community, 2008; WRAP, 2013), as well as Unilever and Walmart encouraging people to 'Turn off the Tap', while lathering hair in the shower to reduce hot water use (Newson et al., 2013).

However, these ways demonstrate how companies are entering the realm of potentially requesting their customers to consume less or at least consume differently, which is difficult (if not impossible) for companies with a high volume economic business model (e.g. Balch, 2013). The incentive for companies does not have to be limited to only maintaining stronger customer brand loyalty by aligning themselves with the green intentions of at least some of their customers; instead, firms may well be incentivised by their power in society and hence their responsibility for taking leadership in sustainability (see e.g. Garriga and Melé, 2004; Heikkurinen and Mäkinen, 2018). Marketing-led companies may be well placed to help consumers to achieve greener lifestyles owing to their knowledge of how to influence consumer behaviour (Vakratsas and Ambler, 1999), while small and medium-sized enterprises may be able to extend their environmental ethic (Tilley, 2000).

Another common approach that companies are now employing for mainstream business is social marketing, and some research has found that influencing social networks is more effective than traditional mass marketing (Berthon et al., 2012). It mainly targets inherent self-interest or social norms (consciously and subconsciously) to change behaviour in the use phase (Collins et al., 2010) in recognition of the idea that consumers' behaviour and choices are an outcome of their attitudes and values at least as much as they are of rational decisions based on costs and information (Spurling et al., 2013). As such, it is one of the extended mechanisms employed by businesses. A well-known example is the hotel towel reuse study by Barr et al. (2011b) where descriptive norms such as 'the majority of guests in this room reuse their towels' influenced far more guests than standard 
environmental statements. For management decisions that can be applied to the sustainability setting, as Guston (2001, p. 1006) suggests that: 'Social marketing is really more of a framework for designing behaviour change programmes than a behaviour change programme in and of itself'.

The last example of how businesses act as change agents and can influence consumers is through so-called product service-systems, as reviewed by Tukker, and Tischner (2006) and Baines et al. (2007) and the opportunity they offer for companies to redesign a consumer offer based on a linear product system to one that includes at least some elements of a service system, in order to reduce the environmental load of the use phase. More recently this has included the wider term the circular economy (Boyes et al., 2009), where businesses are encouraged by governments to innovate (Hill, 2016). While there are some examples for businessto-business products and services (Becken, 2005, Stubbs and Cocklin, 2008), there are only a few practical examples for consumer goods.

If companies are to be agents of change, they require the consent and willingness of their customers. This is gained through a complex and changing relationship and it is important to acknowledge that companies are not the only economic actors spurring change; consumers also influence businesses and co-act with them. One of the key issues that continues to be discussed is the role of the so-called consumercitizens, people accepting the dual role of consumers as users of products/services, and of agents of change by being citizens who influence institutions and organisations on sustainability issues (Barr et al., 2011a). Traditionally the citizen is politically active and engaged, while the consumer is self-interested and economically rational. The citizen has evolved over the last 20 years to use their consumption to further political aims but "we are not talking here simply about groups of activists and progressive entrepreneurs at the margins, but the day-to-day activity of increasing millions of ordinary folk whose regular conduct of leisure and consumption has an ever-stronger political edge' (Scammell, 2000, p. 352).

Attitudinal surveys show that the majority of consumers care about the environment, when asked that question (Fisher et al., 2012; EC, 2014). However, in terms of the practices of mainstream consumers (i.e. what they do when actually shopping), caring for the environment comes bottom of the list but it is still on the list (Moseley 
and Stoker, 2013). Hence, only around 5\% of all mainstream consumer products have ethical or green independent labels, although the figure varies by product category (ECRA, 2016). These products are often linked closely to companies' choice editing activity. The pressure from mainstream consumers manifests when if companies ask them if they care, they state they do, but need help from companies to action the caring. Such a view would somewhat legitimate companies shaping consumer behaviour, giving them almost a licence to socially engineer their customer base.

In addition to reactive mainstream consumers, there is a small, dedicated group of ethical consumers who consciously use their consumption to influence companies and other consumers (Young et al., 2010). Shaw and Newholm (2002, p. 168) explain that the emergence of the ethical consumer in the early 2000s was due to the 'the inextricable link between consumption and ethical problems, such as environmental degeneration and fairness in world trade'. Ethical consumers use a suite of tools to buy ethically (see Shaw and Newholm's (2002) for a categorisation of such tools). Ethical consumers constitute a small but vocal pressure group pressing companies to improve their behaviour, and it is usually those same ethical consumers who are most active in communicating with the customer relations teams and sustainability managers of companies asking for transparency and more ethical product availability. Ethical consumers also support small ethical businesses and sustainable entrepreneurs who try to provide ethical products and services. These companies often pioneer new means of supply, such as organic produce, that are in time absorbed into mainstream business and accepted by mainstream consumers.

Both ethical and some mainstream consumers are reported to use membership of and activism with pressure groups to put pressure on businesses through campaigning and direct action, as well as through multi-stakeholder partnerships (Spaargaren and Mol, 2008). This is well charted, but more often partnerships are used proactively to engage companies. It is worth mentioning a small niche group of people who have decided to not participate, or have low participation rates for the consumption of products and services from companies. These are called voluntary simplifiers, and they reject material consumption in favour of self-sufficiency and contributing to community group efforts to produce food, housing, and other essentials (McDonald et al., 2006). These radical green consumers even 'reject their received subjectivity 
as consumers' (Moisander and Pesonen, 2002, p. 329). Albeit there is little pressure through economic transactions with companies from voluntary simplifiers, they can influence businesses through their activity in pressure groups and their use of social media to influence mainstream consumers (Soma et al., 2016). Without the cooperation of the consumer-citizen, managers in big brand firms would struggle to implement their extended eco-efficiency strategy. The interaction between the private and democratic spheres is becoming more important and the initiative seems to come from influential multinational brands, pressure groups, and consumercitizens, leaving government in the background.

The supply and demand side examples make it clear that business and consumption have undergone important changes in the twenty-first century that are relevant for sustainability. However, as strong sustainability researchers point out, while these changes may have been successful in improving the quality of both consumption and production activities, they have not solved the problem of quantity. That is, effective means to decrease the size of the global economy remain to be discovered. Despite their mixed sustainability record, MNCs selling consumer goods ('big brands') are ideally placed to be a catalyst for change and make a meaningful contribution in the production-consumption nexus (Dauvergne and Lister, 2012) (see Figure 1). Hitherto, the approach taken by MNCs to sustainability has tended to involve the adoption of eco-efficiency measures to manage their operations, as well as their supply chains (Sullivan and Gouldson, 2017; Dauvergne and Lister, 2012). The approaches, tools, policies, and impacts of this strategy are well documented in the previous literature (e.g. Guo et al., 2017; Caiado et al., 2017).

What has not been conceptualised is the extension of eco-efficiency strategies that have started to emerge through companies (especially through big brands) implementing activities to influence the actions of their customers on sustainability issues (Morgan, 2015; Newson et al., 2013), and examples of this were given earlier. Also, the Asda supermarket group now encourages its customers to reduce food waste (Young et al., 2017) and its parent company, Walmart, has impacted thousands of its suppliers through requiring them to meet sustainability standards (Humes, 2011). It is important to theorise about this activity, where the company not only seeks to make its own operations efficient but also those of both its suppliers and its 
customers, as extended eco-efficiency. As it seems that this is a larger trend leading to a broad-scaled implementation of the extended eco-efficiency strategy.

With these examples, it can be noted that big brand companies are already adopting the extended eco-efficiency strategy to make their products eco-efficient over the whole course of their lifetimes. Doing so makes it possible for the firms to tread the path between showing society that they are striving to be sustainable and surviving financially in the ultra-competitive economic system. However, while big brands are setting out to address the quality of consumption within the private sphere, this is certainly inadequate from the broader macro-level point of view. To make the connection between the micro- and macro-level activities, an extended ecosufficiency strategy where the brand company seeks to also reduce the amount of production/consumption is needed. However, as economic actors within the private sphere, and requiring to address both the quality and quantity issue, big brands would arguably require support from the public sphere to exert more pressure on economic actors to spur sustainable change.

\section{Discussion}

As Dyllick and Hockerts (2002) argue, a business that focuses solely on ecoefficiency misses a number of important opportunities to become more sustainable. Furthermore, eco-efficiency in isolation risks continuing overconsumption and counter-productive rebound effects (Lorek and Fuchs, 2013). Thus, it can be stated that sustainable change cannot be delivered merely by improving the quality of the products and services offered in the market; the quantity of the economic activity must also be taken adjusted. In other words, to contribute to sustainable change, the quality of supply and demand must increase and the quantity must decrease. These are the two dimensions that must be taken into account in business strategies aiming to influence action in the public or private sphere. Businesses could conduct an evaluation/analysis of the different mechanisms available to them to create sustainable change and review how they position themselves within these two crucial dimensions of sustainable change. 
In figure 2, the article displays the four different business strategies deduced from the review on a 2 by 2 matrix. The y-axis represents the potential of a strategy to increase the quality of production/consumption, while the $\mathrm{x}$-axis presents the potential to decrease the quantity of production/consumption. The sustainable change strategy (in the upper right hand corner) is certainly the most desirable, as it has the double function of reducing the amount of production/consumption and increasing the quality of the supply/demand. To date, business strategies have mainly addressed the quality aspect via eco-efficiency strategies, and so have neglected the question of quantity. The quantity of production/consumption aspect, however, is now increasing in importance as the planetary limits (Rockström et al., 2009) have been transgressed and the key driver of climate change is economic growth (IPCC, 2014). In the previous literature, an eco-sufficiency strategy, in which manufacturers and consumers voluntarily restrict production and consumption respectively, would partly address the question of quantity in production and consumption, but has been found wanting for strong sustainability (Heikkurinen and Bonnedahl, 2013; Bocken and Short, 2016) because of rebound effects (Figge et al., 2014). Indeed, the ecosufficiency strategy must extend to consumers as a whole, to reduce the quantity of overall activity, as shown in Figure 2, in order to have any significant effect, since, if only one company reduces production, the consumer can buy the goods and services from another firm. Hence, reduction of consumption is of crucial relevance for sustainable change. Accordingly, to complement what is termed in this study the extended eco-efficiency strategy, the article deducts that there is a need for extended eco-sufficiency in proactive business action for sustainability.

Figure 2: Combining extended eco-efficiency and eco-sufficiency for sustainable change

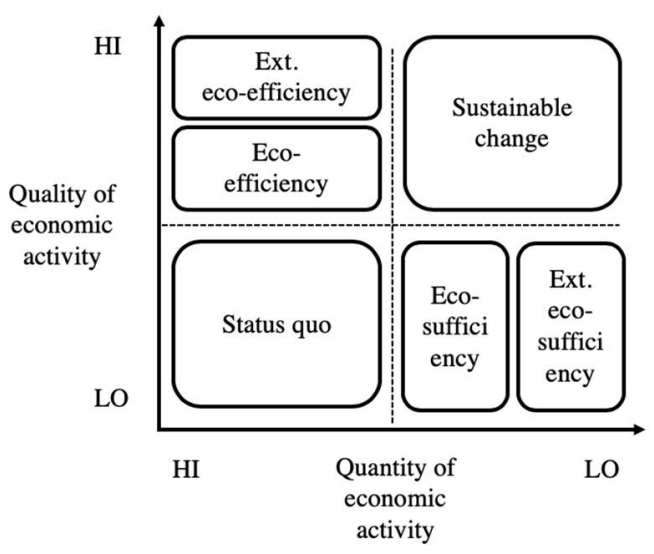


It is certainly a major challenge for business in the private sphere to deal with the issue of overconsumption and overproduction. Perhaps because of this, existing management models - with a few exceptions (e.g. Dyllick \& Hockerts, 2002; Young and Tilley, 2006; Figge et al., 2014; Shrivastava, 2015) - have not really taken the quantitative side of sustainable change into consideration. Interestingly, however, the leading businesses in sustainability have come to understand this paradox of selling sustainable products, but selling more of it. The founder of Patagonia, for instance, has repeatedly told the customer base of the company to buy less of its output. Mr. Chouinard (2013) writes in the Guardian:

\footnotetext{
We are questioning what Patagonia can do, as a company making some of this stuff, to lead us into the next, more responsible economy. What we are reaching toward is an economy that does not rely on insatiable consumerism as its engine, an economy that stops harmful practices and replaces them with either new, more efficient practices or older practices that worked just fine. An economy with less duplication of consumer goods, less throw-away-and-close-your-eyes. We don't know exactly how this will play out. But we do know that now is the time for all corporations to think about it and act.
}

The follow-up question is of course how to act. In one sense, Patagonia's extended eco-sufficiency rhetoric has not been successful, as the sales of the firm's products have continued to increase. The firm could have decided to produce fewer products, but chose not to. This highlights the difficulty, if not the impossibility, of creating a sustainable economy without the support of the public sphere. Thus, the understanding of the interplay between the private sphere, public sphere, and biosphere is a precondition for imagining businesses that could truly influence a reduction in the quantity of economic activity.

In addition to acknowledging the key role of public actors, a precondition that becomes evident in the quote by Chouinard is admitting the responsibility of the supply side for the prevailing unsustainability. He is very clear that the responsibility for sustainable change cannot be limited to producing or selling goods and services efficiently and in a less environmentally damaging manner, but he also questions the demand generated. The biosphere, which all human systems are both embedded in and dependent on, is limited in terms of both inputs and outputs. Ever-increasing consumption and production on a finite planet is a physical impossibility (Georgescu-Roegen, 1975; Daly, 1992); but as mentioned above, the managers' role in making these decisions towards sustainable change is a tough one. Strategic 
management has to balance all the interests that manifest in their line of business, including the abstract limits set by the biosphere, as well as the needs and wants that unfold in the public and private spheres.

Hence, it remains an open question whether big brands are able to take all the required interests into account in their operations. Fortunately, however, it is not only the responsibility of the private sector to create sustainable change, but essentially also the task of the public sphere (Heikkurinen and Mäkinen, 2018). Businesses have to date mainly attempted to influence the political and legislative actors, so that changes implemented in the private sphere favour their interests of increasing sales and enabling further economic growth. As MNCs have already been shown to influence politics by exerting their power (Banerjee, 2008; Scherer and Palazzo, 2011), the article ponders whether the link between the businesses and the public sector could also be used to support laws and regulations that would set higher taxes or even caps on the consumption/production. At first sight, businesses asking the public actors to regulate the private sphere would seem to go against the market logic of the private sphere but on closer inspection, it could provide competitive advantage to those companies that are progressive and able to produce the required higherquality goods. Furthermore, as the limitations of igniting sustainable change in the economic sphere become clear, managers are under an ethical imperative to persuade governments to regulate the quantity of economic activity.

Accordingly, the implications of the study are that businesses should not be limited to trying to make consumers to buy better or use their products in a more efficient way (increased quality), but also to consume less (decreased quantity). For instance, sustainability management could discuss how they could contribute to creating stronger legislative frames for the private sphere to reduce the quantity of production and consumption. It might be that even now some business leaders are using lobbying as a means to progress stricter regulations on production and consumption as part of their strategy for sustainable change. This area merits more scholarly attention.

\section{Conclusion}


As a response to MNCs taking action regarding the prevailing unsustainable development, the article examined how business strategies on the micro-level could effectively address issues of sustainability on the macro-level. The conceptualised 'extension' in strategy signifies that firms not only focus on their own sustainability operations but also seeks to influence activities of others. Due to their power and position in the supply chain, firms of significant brand value are well suited to change production and consumption patterns through extended eco-efficiency.

While pursuing an extended eco-efficiency strategy is important, it is considered to be an inadequate way to spur sustainable change as it emphasises the quality side of economic activity. It is therefore apparent that an effective approach to sustainability would have to feature means for both improving quality and decreasing quantity (Figure 2). Hence, it can be concluded that an effective business strategy to sustainable change increases both the quality of production (eco-efficiency) and decreases the amount of production (eco-sufficiency), as well as influence customers to consume better (extended eco-efficiency) and less (extended eco-sufficiency).

While studying the role of business for sustainability, it is important to note that the potential for sustainable change is not rooted in a single actor or mechanism but relies on a different set of catalysts for eco-efficiency and eco-sufficiency. That is: as the logic, actors, and mechanisms of the private sphere are largely insufficient to decrease the quantity of economic activity, the article advises action also in the public sphere. Consumers should engage in the role of citizens in the public sphere, while businesses could lobby for stricter sustainability regulations, yet respect the democratic logic of the public sphere, as suggested by Heikkurinen and Mäkinen (2018). While the present article enables the examination of the effectiveness of businesses as change agents for sustainability, context specific empirical studies are encouraged. 


\section{References}

Albino, V., Balice, A., and Dangelico, R. M. (2009), "Environmental strategies and green product development: an overview on sustainability-driven companies", Business Strategy and the Environment, 18(2): 83-96.

Assadourian, E. (2010), "Transforming cultures: From consumerism to sustainability", Journal of Macromarketing, 30(2): 186-191.

Auld, G., A. Mallett, B. Burlica, F. Nolan-Poupart and R. Slater (2014), "Evaluating the effects of policy innovations: Lessons from a systematic review of policies promoting low-carbon technology”, Global Environmental Change, 29: 444458.

Autio, M., Heiskanen, E., \& Heinonen, V. (2009). "Narratives of 'green'consumers-the antihero, the environmental hero and the anarchist", Journal of Consumer Behaviour: An International Research Review, 8(1): 4053.

Baines, T. S., H. W. Lightfoot, S. Evans, A. Neely, R. Greenough, J. Peppard, R. Roy, E. Shehab, A. Braganza, A. Tiwari, J. R. Alcock, J. P. Angus, M. Bastl, A. Cousens, P. Irving, M. Johnson, J. Kingston, H. Lockett, V. Martinez, P. Michele, D. Tranfield, I. M. Walton, H. Wilson (2007), "State-of-the-art in product-service systems", Proceedings of the Institution of Mechanical Engineers, Part B: Journal of Engineering Manufacture, 221(10): 1543-1552.

Balch, Ol. (2013), "H\&M: can fast fashion and sustainability ever really mix?", The Guardian (3 May).

Banerjee, S. B. (2003), "Who sustains whose development? Sustainable development and the reinvention of nature", Organization Studies, 24(1): 143180.

Banerjee, S. B. (2008), "Corporate social responsibility: The good, the bad and the ugly", Critical sociology, 34(1): 51-79.

Barad, K. (2003). "Posthumanist performativity: Toward an understanding of how matter comes to matter", Signs: Journal of Women in Culture and Society, 28(3): 801-831.

Barr, S., A. Gilg and G. Shaw (2011a), "Citizens, consumers and sustainability: (Re)Framing environmental practice in an age of climate change", Global Environmental Change, 21(4): 1224-1233. 
Barr, S., A. Gilg and G. Shaw (2011b), “'Helping People Make Better Choices': Exploring the behaviour change agenda for environmental sustainability", Applied Geography, 31(2): 712-720.

Becken, S. (2005), "Harmonising climate change adaptation and mitigation: The case of tourist resorts in Fiji", Global Environmental Change, 15(4): 381-393.

Belk, R. (2014), "You are what you can access: Sharing and collaborative consumption online", Journal of Business Research, 67(8): 1595-1600.

Berthon, P. R., L. F. Pitt, K. Plangger, and D. Shapiro (2012), "Marketing meets Web 2.0, social media, and creative consumers: Implications for international marketing strategy", Business Horizons, 55(3): 261-271.

Bhatti, M. (1993), "From consumers to prosumers: housing for a sustainable future", Housing Studies, 8(2): 98-108.

Bocken, N. M. P. and S. W. Short (2016), "Towards a sufficiency-driven business model: Experiences and opportunities", Environmental Innovation and Societal Transitions, 18: 41-61.

Bocken, N. M. P. and J. M. Allwood (2012), "Strategies to reduce the carbon footprint of consumer goods by influencing stakeholders", Journal of Cleaner Production, 35: 118-129.

Boyes, E., K. Skamp and M. Stanisstreet (2009), “Australian Secondary Students' Views About Global Warming: Beliefs Abo", Research in Science Education, 39(5): 661-680.

Business in the Community (2008), "Procter \& Gamble - Ariel Turn to 30." Retrieved April 17th, 2012, from http://www.bitc.org.uk/resources/case_studies/pg_rm.html.

Caiado, R. G. G., de Freitas Dias, R., Mattos, L. V., Quelhas, O. L. G. and Leal Filho, W. (2017), "Towards sustainable development through the perspective of ecoefficiency-A systematic literature review", Journal of Cleaner Production, 165: 890-904.

Carter, C. and D. Rogers (2008), "A framework of sustainable supply chain management: moving toward new theory", International Journal of Physical Distribution \& Logistics Management, 38(5-6): 360-387.

Castree, N. (2010), "Neoliberalism and the biophysical environment: a synthesis and evaluation of the research", Environment and Society: Advances in Research, 1(1): 5-45. 
Chouinard, Y. (2013), "Prosperity with less: what would a responsible economy look like?" Guardian (4 October).

Collins, K., A. Tapp and A. Pressley (2010), "Social marketing and social influences: Using social ecology as a theoretical framework", Journal of Marketing Management, 26(13-14): 1181-1200.

Daly, H. E. (1992), "Allocation, distribution, and scale: towards an economics that is efficient, just, and sustainable", Ecological Economics, 6(3): 185-193.

Dangelico, R. M., and D. Pujari (2010), "Mainstreaming green product innovation: Why and how companies integrate environmental sustainability", Journal of Business Ethics, 95(3): 471-486.

Dauvergne, P. and J. Lister (2012), "Big brand sustainability: Governance prospects and environmental limits", Global Environmental Change, 22(1): 36-45.

DeSimone, L. D. and F. Popoff (2000), Eco-efficiency: the business link to sustainable development, MIT Press: Cambridge, Massachusetts.

DesJardins, J. (1998), “Corporate environmental responsibility”. Journal of Business Ethics, 17(8): 825-838.

Dyllick, T. and K. Hockerts (2002), "Beyond the business case for corporate sustainability", Business Strategy and the Environment, 11(2): 130-141.

EC (2014), "416: Attitudes of European citizens towards the environment", Eurobarometer, Special, $\quad$ Retrieved 01/10/14, from http://ec.europa.eu/public_opinion/archives/ebs/ebs_416_en.pdf.

ECRA (2016), Ethical consumer market report 2015, Retrieved 01/05/16, from http://www.ethicalconsumer.org/researchhub/ukethicalmarket.aspx.

Evans, S., D. Vladimirova, M. Holgado, K. Van Fossen, M. Yang, E. A. Silva and C. Y. Barlow (2017), "Business model innovation for sustainability: Towards a unified perspective for creation of sustainable business models", Business Strategy and the Environment, 26(5): 597-608.

Figge, F., W. Young, and R. Barkemeyer (2014), "Sufficiency or efficiency to achieve lower resource consumption and emissions? The role of the rebound effect", Journal of Cleaner Production, 69: 216-224.

Fisher, C., S. Bashyal and B. Bachman (2012), "Demographic impacts on environmentally friendly purchase behaviors", Journal of Targeting, Measurement and Analysis for Marketing, 20(3-4): 172-184.

Foxon, T.J. (2011), “A coevolutionary framework for analysing a transition to a sustainable low carbon economy", Ecological Economics, 70(12): 2258-2267 
Fuchs, D., A. Di Giulio, K. Glaab, S. Lorek, M. Maniates, T. Princen, and I. Røpke (2016), "Power: the missing element in sustainable consumption and absolute reductions research and action", Journal of Cleaner Production 132: 298-307.

Garriga, E. and D. Melé (2004), "Corporate social responsibility theories: Mapping the territory", Journal of Business Ethics, 53(1-2): 51-71.

Georgescu-Roegen, N. (1975), "Energy and economic myths", Southern Economic Journal, 41: 347-381.

Girod, B., D. P. van Vuuren and E. G. Hertwich (2014), "Climate policy through changing consumption choices: Options and obstacles for reducing greenhouse gas emission", Global Environmental Change, 25: 5-15.

Goworek, H., T. Fisher, T. Cooper, S. Woodward and H. Alex (2013), "The sustainable clothing market: an evaluation of potential strategies for UK retailers", International Journal of Retail \& Distribution Management, 40(12): 935-955.

Guo, Y., Liu, W., Tian, J., He, R., \& Chen, L. (2017), “Eco-efficiency assessment of coal-fired combined heat and power plants in Chinese eco-industrial parks", Journal of Cleaner Production, 168: 963-972.

Guston, D. H. (2001), "Boundary Organizations in Environmental Policy and Science: An Introduction”, Science, Technology \& Human Values, 26(4): 399408.

Heikkurinen, P. (2010), "Image differentiation with corporate environmental responsibility", Corporate Social Responsibility and Environmental Management, 17(3): 142-152.

Heikkurinen, P. and K. J. Bonnedahl (2013), "Corporate responsibility for sustainable development: a review and conceptual comparison of market- and stakeholder-oriented strategies", Journal of Cleaner Production, 43: 191-198.

Heikkurinen, P. and S. Forsman-Hugg (2011), "Strategic corporate responsibility in the food chain", Corporate Social Responsibility and Environmental Management, 18(5): 306-316.

Heikkurinen, P. and J. Mäkinen, J. (2018), "Synthesising Corporate Responsibility on Organisational and Societal Levels of Analysis: An Integrative Perspective", Journal of Business Ethics, 49(3): 589-607.

Heikkurinen, P., J. Rinkinen, T. Järvensivu, K. Wilén and T. Ruuska (2016), "Organising in the Anthropocene: an ontological outline for ecocentric theorising”, Journal of Cleaner Production, 113: 705-714. 
Hill, J. (2016), "Circular Economy and the Policy Landscape in the UK", Taking Stock of Industrial Ecology, Springer International Publishing, pp. 265-274.

Hukkinen J. (2001), "Eco-efficiency as abandonment of nature". Ecological Economics, 38(3): 311-315.

IPCC (2014), "5th Assessment Report. Climate change 2014: Impacts, Adaption, and Vulnerability", Working Group II. Geneva: Intergovernmental Panel on Climate Change.

Johnston, J. (2008), "The citizen-consumer hybrid: ideological tensions and the case of Whole Foods Market", Theory and Society, Vol. 37, No. 3, pp. 229-270.

Kilbourne, W., P. McDonagh and A. Prothero (1997), "Sustainable consumption and the quality of life: A macromarketing challenge to the dominant social paradigm", Journal of Macromarketing, 17(1): 4-24.

Lang, T. and D. Barling (2012), "Food security and food sustainability: reformulating the debate", The Geographical Journal, 178: 313-326.

Lee, N., Y. J. Choi, C. Youn and Y. Lee (2012), "Does Green Fashion Retailing Make Consumers More Eco-friendly? The Influence of Green Fashion Products and Campaigns on Green Consciousness and Behavior", Clothing and Textiles Research Journal, 30: 67-82.

Lockie, S. (2009), "Responsibility and agency within alternative food networks: assembling the "citizen consumer", Agriculture and Human Values, 26(3): 193-201.

Lorek, S. and D. Fuchs (2013), "Strong sustainable consumption governanceprecondition for a degrowth path?", Journal of Cleaner Production 38: 36-43.

Mäkinen, J. and A. Kourula (2012), "Pluralism in political corporate social responsibility”, Business Ethics Quarterly, 22(4): 649-678.

Martin, C. J., P. Upham and R. Klapper (2017), “Democratising platform governance in the sharing economy: An analytical framework and initial empirical insights", Journal of Cleaner Production, 166: 1395-1406.

McDonald, S., C. J. Oates, C. W. Young and K. Hwang (2006), "Toward sustainable consumption: Researching voluntary simplifiers", Psychology and Marketing, 23: 515-534.

Memery, J., P. Megicks and J. Williams, (2005), "Ethical and social responsibility issues in grocery shopping: a preliminary typology", Qualitative Market Research: An International Journal, 8(4): 399-412. 
Moisander, J. and S. Pesonen (2002), "Narratives of sustainable ways of living: constructing the self and the other as a green consumer", Management Decision, 40(4): 329-342.

Morgan, E. (2015), "Plan A: Analysing Business Model Innovation for Sustainable Sustainable Consumption in Mass-Market Clothes Retailing", Journal of Corporate Citizenship, 57: 73-98.

Moseley, A. and G. Stoker (2013), "Nudging citizens? Prospects and pitfalls confronting a new heuristic", Resources, Conservation and Recycling, 79: 410.

Murillo-Luna, J. L., C. Garcés-Ayerbe and P. Rivera-Torres (2011), "Barriers to the adoption of proactive environmental strategies", Journal of Cleaner Production, 19: 1417-1425.

Mylan, J. (2017), “The Business of 'Behaviour Change': Analysing the ConsumerOriented Corporate Sustainability Journey of Low-Temperature Laundry", Organization \& Environment, 30: 283-303

Newholm, T. and D. Shaw (2007), "Studying the ethical consumer: A review of research", Journal of Consumer Behaviour, 6(5): 253- 270.

Newson, R. S., R. Lion, R. J. Crawford, V. Curtis, I. Elmadfa, G. I. Feunekes, C. Hicks, M. van Liere, C. F. Lowe, G. W. Meijer, B. Pradeep, K. S. Reddy, M. Sidibe and Uauy, R. (2013), "Behaviour change for better health: nutrition, hygiene and sustainability", BMC Public Health 13(1): 13.

Norgaard, R. B. (1994), Development betrayed: The end of progress and a coevolutionary revisioning of the future. Routledge: London.

Peattie, K. and F-M. Belz (2010), "Sustainability marketing-An innovative conception of marketing", Marketing Review St. Gallen, 27(5): 8-15.

Porter, M. E. and M. R. Kramer (2006), "The link between competitive advantage and corporate social responsibility", Harvard Business Review, 85: 78-92.

Ritzer, G. and N. Jurgenson (2010), "Production, Consumption, Prosumption The nature of capitalism in the age of the digital "prosumer"', Journal of Consumer Culture, 10(1): 13-36.

Rockström J., Steffen, W., Noone, K., Persson, Å., Stuart Chapin, F., Lambin, E., Lenton, T. M., Scheffer, M., Folke, C., Schellnhuber, H. J., Nykvist, B., De Wit, C. A., Hughes, T., Van der Leeuw, S., Rodhe, H., Sörlin, S., Snyder, P. K., Costanza, R., Svedin, U., Falkenmark, M., Karlberg, L., Corell, R. W., Fabry, V. H., Hansen, J., Walker, B., Liverman, D., Richardson, K., Crutzen, 
P. and Foley, J. (2009), "Planetary Boundaries: Exploring the Safe Operating Space for Humanity", Ecology and Society, 14(2): 32.

Scammell, M. (2000), "The internet and civic engagement: the age of the citizenconsumer", Political Communication, 17(4): 351-355.

Schäfer, M., M. Jaeger-Erben \& S. Bamberg (2012), "Life Events as Windows of Opportunity for Changing towards Sustainable Consumption Patterns?", Journal of Consumer Policy, 35: 65-84.

Schaltegger, S., F. Ludeke-Freund and E. G. Hansen (2012), "Business cases for sustainability: the role of business model innovation for corporate sustainability", International Journal of Innovation and Sustainable Development, 6: 95-119.

Scherer, A. G. and G. Palazzo (2011), "The new political role of business in a globalized world: A review of a new perspective on CSR and its implications for the firm, governance, and democracy", Journal of Management Studies, 48(4): 899-931.

Seran, S. and M. Izvercian (2014), "Prosumer engagement in innovation strategies: The Prosumer Creativity and Focus Model”, Management Decision, 52(10): 1968-1980.

Shaw, D. and T. Newholm (2002), "Voluntary Simplicity and the Ethics of Consumption", Psychology \& Marketing, 19(2): 167-185.

Shrivastava, P. (2015), "Organizational sustainability under degrowth", Management Research Review, 38(6): 1.

Shrum, L. J., J. A. McCarty and T. M. Lowrey (1995), "Buyer characteristics of the green consumer and their implications for advertising strategy", Journal of Advertising, 24(2): 71-82.

Solomon, M. and N. Rabolt, (2004), Consumer behavior in fashion. Prentice Hall: Englewood Cliffs, N.J..

Soma, K., Onwezen, M.C., Salverda, I. E. and van Dam, R.I. (2016), "Roles of citizens in environmental governance in the Information Age - four theoretical perspectives", Current Opinion in Environmental Sustainability, 18: 122-130.

Smith, A. ([1776] 2012), Wealth of Nations. Wordsworth: London.

Spaargaren, G. and A. P. J. Mol (2008), "Greening global consumption: Redefining politics and authority", Global Environmental Change, 18(3): 350-359. 
Springett, D. (2003), "Business conceptions of sustainable development: A perspective from critical theory", Business Strategy and the Environment, 12(2): 71-86.

Spurling, N. J., A. McMeekin, D. Southerton, E. A. Shove and D. Welch (2013), "Interventions in practice: reframing policy approaches to consumer behaviour." Sustainable Practices Research Group Report. Lancaster University: Lancaster.

Starik, M. and G. P. Rands (1995), "Weaving an integrated web: Multilevel and multisystem perspectives of ecologically sustainable organizations", Academy of Management Review, 20(4): 908-935.

Stubbs, W. and C. Cocklin (2008), "An ecological modernist interpretation of sustainability: the case of Interface Inc", Business Strategy and the Environment 17(8): 512-523.

Stål, H. I. and H. Corvellec (2018), “A decoupling perspective on circular business model implementation: Illustrations from Swedish apparel", Journal of Cleaner Production, 171: 630-643.

Stål, H. I., and J. Jansson (2017), "Sustainable Consumption and Value Propositions: Exploring Product-Service System Practices Among Swedish Fashion Firms”, Sustainable Development, 25(6): 546-558.

Sullivan, R. and A. Gouldson (2017), "The Governance of Corporate Responses to Climate Change: An International Comparison", Business Strategy and the Environment, 26(4): 413-425.

Thaler, R. H. and C. R. Sunstein (2008), Nudge: improving decisions about health, wealth, and happiness. Yale University Press: London.

Tilley, F. (2000), “Small firm environmental ethics: how deep do they go?", Business Ethics: A European Review, 9(1): 31-41.

Tukker, A. and U. Tischner (2006), "Product-services as a research field: past, present and future. Reflections from a decade of research", Journal of Cleaner Production, 14: 1552-1556.

Vakratsas, D. and T. Ambler (1999), "How advertising works: what do we really know?" The Journal of Marketing, 63(1): 26-43.

Van Marrewijk, M. and M. Werre (2003), "Multiple levels of corporate sustainability”, Journal of Business Ethics, 44(2-3): 107-119.

WEF (2013), Engaging tomorrow's consumer, World Economic Forum: Geneva. 
Welford, R., C. W. Young and B. Ytterhus (1998), "Towards sustainable production and consumption: a literature review and conceptual framework for the service sector", Eco-Management and Auditing, 5(1): 38-56.

WRAP (2013), Household food and drink waste in the UK 2012, Waste Resource Action Plan: London.

Young, W. and F. Tilley (2006), "Can businesses move beyond efficiency? The shift toward effectiveness and equity in the corporate sustainability debate", Business Strategy and the Environment, 15(6): 402-415.

Young, W., Hwang, K., McDonald, S. \& Oates, C. J. (2010). "Sustainable consumption: green consumer behaviour when purchasing products", Sustainable Development, 18(1): 20-31.

Young, W., S. V. Russell, C. A. Robinson and R. Barkemeyer (2017), "Can social media be a tool for reducing consumers' food waste? A behaviour change experiment by a UK retailer", Resources, Conservation and Recycling, 117: 195-203.

\section{Acknowledgements}

The authors wish to thank the editor and reviewers of the journal, as well as the comments received on the earlier version of this study at the Corporate Responsibility Research Conference 2016 in Istanbul, Turkey. This is project has received funding from the European Union's Horizon 2020 research and innovation programme under the Marie Sklodowska-Curie grant agreement No 707652. 